\title{
PERDAGANGAN INTERNASIONAL: PENGARUHNYA TERHADAP PERUBAHAN SISTEM NILAI BUDAYA ORANG MALUKU ${ }^{1}$
}

\author{
International Trade: The Implication for the transformation \\ of the cultural value system in the Moluccas
}

\author{
MUS HULISELAN ${ }^{2}$ \\ Program Pascasarjana \\ Universitas Pattimura
}

\begin{abstract}
Abstrak
Keterlibatan Orang Maluku dalam percaturan perdagangan internasional dan perjumpaan dengan berbagai pedagang asing telah membawa perubahan dalam peradaban Orang Maluku. Dari para pedagang asing ini para Sultan dan raja-raja memperoleh pengetahuan tentang: agama, perdagangan, pelayaran maupun berbagai teknologi baru. Perdagangan internasional membawa dampak yang cukup penting bagi kehidupan sosial budaya Maluku, karena menjadi ruang perjumpaan berbagai Negara dengan latar budaya yang berbeda-beda dan berpengaruh terhadap budaya asli Maluku, namun identitas Maluku tetap terjaga, yakni ciri kebudayaan monodualitas. Dalam kebudayaan monodualistis kedua kelompok harus tetap ada dan satu harus memberikan kemungkinan kepada yang lain untuk tetap hidup, sebab kalau satu tidak ada maka keberadaan yang lain tidak berarti. Dalam waktu bersamaan juga tumbuh ikatan-ikatan persaudaraan yang didasarkan pada nilai tolong menolong antar sesama. Hal ini lahir sebagai upaya penegakan keseimbangan baru dalam perbedaan untuk peredam kekerasan dan keinginan untuk hidup berdampingan secara damai.
\end{abstract}

Kata Kunci : Perdagangan, internasional, dinamika, budaya, monodualitas

\begin{abstract}
The involvement of the Moluccan in the international trade and the interaction with the foreign traders has brought the transformation in the civilization of tbe Moluccas. Through these foreign traders sultans and the kings achieving knowledge on religion, trade, seafaring and new technologies. The international trade has created major impacts on the social and cultural life in the moluccas asnit save as a interaction space for countries with variois background and has influenced the original cultural of the Moluccas although the identity of the Moluccas is the existed with the monodualism characteristic. In the perspective of the monodualistic culture every group has to still exist and must depend one another to support every part. As the meaning of one always depends on the existence of the other. In the same time the brotherhood relationship has grew based on tbe mutual benefit principal. This phenomenom was existed as an effort to create the new balance in difference to control the conflict and violence and as a good will to live in peace.
\end{abstract}

Keywords: Trade, International, Dynamics, Culture, Monodualistic

\section{Pendahuluan}

Nama Maloko (Maluku), pada mulanya ditujukan kepada beberapa pulau kecil yang terdapat di Maluku Utara yaitu Ternate, Tidore, Bacan dan Makian, sebagai pulau- pulau penghasil rempah-rempah (cengkih). Tetapi dari sumber lain rnenyebutkan bahwa yang dimaksudkan dengan Maluku adalah wilayah kekuasaan 4 (empat) Kesultanan yang meliputi Kesultanan Ternate, Tidore,

1. Makalah ini pernah dipresentasikan dalam Seminar Sail Banda pada tanggal 2 Agustus 2010 di Ambon dengan tema "Perairan Maluku dalam Jalur dan Jaringan Perdagangan International Masa Lampau dan Kini".

2. Guru Besar Antropologi Sosial pada Universitas Pattimura 
Bacan dan Jailolo dan ini dikuatkan dengan adanya istilah Maloko Kie Raha (Empat Penguasa Raja di Maluku).

Walaupun Maluku sudah dikenal ribuan tahun yang lalu,tetapi dilain sisi nama dan letak wilayah ini pada awalnya dirahasiakan oleh berbagai pelayar maupun pedagang bangsa asing (Cina, India, Arab, Turki dan Persia) yang saat itu memainkan peranan penting dalam Perdagangan Internasiona rempah-rempah. Upaya menyembunyikan dapat dilihat dari berbagai cerita yang dikembangkan antara lain: Bahwa di timu (wilayah penghasil rempah-rempah) adalah ujung dunia yang curam dan berbahaya untuk pelayaran dan siapa yang tiba disitu akan terperosok dan tidak mungkin kembali lagi.

Kerahasiaan ini sangat penting karena nilai rempah-rempah di Eropa saat itu melebih nilai emas ( $1 \mathrm{~kg}$ cengkih sama nilainya dengan $7 \mathrm{~kg}$ emas) dan hanya digunakan oleh para Raja-Raja dan Bangsawan Tinggi. Tingginya nilai rempah-rempah dapat dibaca pula dari pernyataan seorang Pedagang Arab demikian:

Bila anda memuat cengkih keempat kapal dan tiga kapal tenggelam, maka dengan keuntungan dari penjulan muatan satu kapal yang tersisa, kerugian satu ditimbulk lainnya dapat kembali dan sisanya masih cukup besar bagi anda (Amal 2010: 357).

Dalam buku Nagara Kartagama terbitan India yang ditulis kira-kira 200 SM, bahwa cengkih telah digunakan sebagai ramuan obat-obatan.

Cerita-cerita tentang dunia yang datar dan timur sebagai ujung dunia, tidak mampu membendung jiwa petualangan para pelau Portugis, Spanyol dan Eropa lain untuk menemukan dunia baru penghasil rempahrempah itu.Sebelum Orang Eropa mencapa dunia rempah-rempah perdagangan rempahrempah dilakukan melalui dua jalur, 1). Jalur darat mulai dari Maluku - Cina melalui dara (jalan sutra) - Timur Tengah; 2). Jalur laut mulai dari Maluku - Jawa - Malaka - India
(Gujarat) - Arabia - Teluk Persia sampai ke Aleksandria. Dengan kehadiran bangsa Eropa di Maluku (Portugis tahun 1512, Spanyol tahun 1521, Belanda tahun 1599 dan Inggris tahun 1521, Belanda tahun 1599 dan Inggris rempah-rempahnya dan menguasainya, merupakan babakan sejarah baru. Maluku telah menjadi ajang perebutan pengaruh dan kekuasaan antar berbagai kekuatan. Peristwa ini telah membawa berbagai perubahan terhadapSistem Nilai Budaya Orang Maluku.

Mengingat keanekaragaman etnik, budaya, bahasa dan adat istiadat yang sangat tinggi, penulisan ini akan dibatasi hanya pada penduduk yang mendiami wilayah Ambon, Seram, Lease dan Banda. Daerah yang lain akan dibahas apabila memiliki kaitan kesejarahan dan Perdagangan Internasiona dengan ke empat wilayah tersebut diatas.

\section{Kepulauan Maluku Dan Penduduknya}

Hasil penelitian bahasa menunjukkan bahwa Penduduk Asli Maluku tergolong Orang Austronesia karena sebagian besar penduduknya pendukung bahasa Austronesia. Sebanyak 117 bahasa lokal yang terdapa di Maluku, 16 bahasa di Halmahera Utara merupakan bahasa Non Austronesia dan 1 (satu) di Maluku Barat Daya yaitu bahasa Oirata (Taber Mark, 1996: 312). Walaupun sebagian besar penduduknya merupakan suku bangsa yang berasal dari rumpun bahasa yang sama tetapi pada kenyataannya masyarakat Maluku sebagai masyarakat kepulauan, memiliki keanekaragaman budaya yang tinggi.

Penutur Bahasa Austronesia memasuki wilayah Maluku dalam dua gelombang. Gelombang pertama adalah Orang-Orang Proto Melayu dan Gelombang kedua OrangOrang Deutro Melayu. Di wilayah Seram, Ambon dan Lease, Orang-Orang Proto Melayu dikenal sebagai Orang Alune atau dikenal juga dengan sebutan Uli atau Pata (kelompok) Alune dan Orang-Orang Deutro Melayu sebagai Orang Wemale atau disebut juga Uli atau Pata (kelompok) Wemale.
Kemudian dalam perkembangannya, kedua kelompok ini masing-masing membentuk dan membangun identitas diri mereka yang berasaskan ideologi Siwa (Sembilan) dan Lima. Berdasarkan ideologi tersebut, Uli Alune adalah penganut ideologi Siwa yang mengidentifikasi diri mereka sebagai $\boldsymbol{U l i}$ atau Pata Siwa dan Uli Wemale sebagai penganut ideologi Lima, mengidentifikasi diri mereka Uli atau Pata Lima. Persekutuan Sembilan dan Lima dapat dijumpai pula di Kepulauan Kei sebagai: Ur Siuw (kelompok sembilan) dan Lor Lim (kelompok lima); Kepulauan Aru: Uru Siwa dan Uru Lima dan di Kepulauan Banda Or Siang dan Or Lima

Persekutuan Siwa dan Lima, pada tataran ideologi, tidak memiliki pemimpin dan wilayah atau teritori kekuasaan. Pada tataran politik, terdapat berbagai Uli atau Aman sebagai kerajaan-kerajaan kecil dengan memiliki struktur pemerintahan yang teratur, memiliki rakyat dan wilayah kekuasaan. Misalnyadi di Jasirah Hitu (Ambon) terdapat Misalnyadi di Jasirah Hitu (Ambon) terdapat Uli Helawan (Kesatuan Kencana) termasuk Uli
Lima. Struktur pemerintahannyamengadopsi struktur tubuh manusia yaitu: Raja Hitu (Pelu) berstatus Kepala, Perdana Tanahitumesing (Kapitan) berstatus Tangan Kanan, Pati Tuban berstatus Tangan Kiri, Nusatapi berstatus Kaki Kanan dan Totohatu adalah Kaki Kiri. Raja Hitu dan Empat Perdana pembentuk Uli dikisahkan berasal dari berbagai daerah di Nusantara yaitu: Raja Hitu (Kepala) merupakan penduduk asli Hitu, Tanhitumesing (Tangan Kanan)Alifuru berasal dari Seram, Pati Tuban (tangan Kiri) dari Jawa, Nusatapi (kaki kanan) dari Jailolo dan Totohatu (Kaki kiri) berasal dari Bali yang melalui Gorom berlayar ke Hitu; (Jansen, 1977: 101). Hal ini mengindikasikan bahwa panduduk pesisir Pulau Ambon merupakan campuran antara penduduk asli dengan berbagai pedagang dan pelayar yang datang kedaerah ini untuk berdagang. Struktur Pemerintahan yang demikian dapat dijumpai juga antara lain pada: Uli Hatuhaha (Uli Lima) di Pulau Haruku, dan Uli Nusaniwe (Uli Siwa) di Jazirah Leitimor.
Struktur Tubuh Manusia telah dipakai oleh Siwa maupun Lima sebagai pedoman penyusunan struktur pemerintahan Uli, karen dianggap secara biologis tubuh manusialah yang paling sempurna. Masing-masing anggota tubuh memiliki status dan fungs yang saling menunjang dan saling melengkapi untuk mencapai satu kesempurnaan. Biasanya Uli Lima pada tataran Politik dianggap sebagai kesatuan dari Lima Hena dan Uli Siwa merupakan kesatuan dari Sembilan Aman, walaupun pada kenyataannya banyak Uli tidak mencukupi jumlah tersebut.

Uli dikepalai oleh seorang Raja yang bergelar Upu Latu dan merupakan gabungan dari beberapa Aman ( $A m a=$ Bapak $)$ atau Hen $(\operatorname{In} a=\mathrm{Ibu})$. Hena dan Aman adalah kelompok genealogis, teritoroal dan religius. Kelompok genealogis, teritorial dan religius adalah kelompok yang dipersatukan berdasarkan ikatan keturunan yang sama, mendiami dan memiliki wilayah yang sama dan mendukung adat yang sama. Aman atau Hena merupakan kelompok yang memiliki solidaritas yang tinggi sebagai orang-orang seketurunan, setanah air dan satu kepercayaan. Ada kemauan berkorban untuk sesama dalam menjaga Aman atau Hena sebagai satu komunitas tunggal.

Aman atau Hena merupakan gabungan beberapa Luma Tau atau Mata Ruma (Marga) Luma Tau adalah satu kelompok kerabat genealogis yang ditarik dari garis ayah. Wilayah atau teritori pemukiman dari satu Luma Tau disebut Uku. Setiap Luma Tau dipimpin oleh seorang yang dianggap tertua, terkemuka dan berwibawa, Luma Tau terkemuka dalam satu Aman disebut Luma Latu dan dari Luma Latu inilah pemimpin Aman (Upu Aman) berasal yang kemudian mereka ini disebut Orang Kaya. Dalam satu Uli biasanya terdapat satu Aman atau Hena yang terpandang dan terkemuka yang dinamakan Aman Latu atau Ina Latu, yang lebih besar pengaruhnya dari pada Aman yang lain dan salah seorang yang terkemuka dariAman Latu atau Ina Latu akan menjadi Upu Latu (Raja) dari Uli tersebut. 
Bagaimana kehidupan penduduk pulau rempah-rempah pada abad $15 \mathrm{~s} / \mathrm{d}$ pertengahan abad 16 dapat diketahui melalui berbaga kisah, baik yang diceritakan oleh Rijali penulis Asia asal Hitu maupun Orang Eropa sebagai berikut:

1). Menurut Rijali, kira-kira sampai permulaan abad ke 15 penduduk permulann abio ke lisi Ternate hich dalom lar dan primitif dan menggunakan kulit kayu daun- daun dan lainlain untuk menutupi tubuh mereka Nanti setelah Ternate dibawah pemerintahan Kaicili Gapi Baguna (1432-1465) Ia mengundang para pedagang Cina, Arab dan Jawa yang sejak lama telah mengadakan relas dagang dengan pulau-pulau ini untuk menetap dan dengan demikian merek dapat menularkan pengetahuan apat menularkan pengetahua dan keterampilannya yang suda ebih maju kepada penduduk asli. la mengarahkan masyarakatnya supaya dapat menerima orangorang asing ini dan belajar rahasia pengetahuan mereka. Maka tak lama kemudian penduduk Ternate mulai menggunakan tekstil yang dijual orang-orang asing itu, mula menanam kapas dan menenun kain. Membangun rumah dan membuat perahu dengan teknik yang lebih perahu dengan teknik yang lebih canggih dan secara perlahan lahan mereka muin laku dan budi pekerti mereka yang kasar. Dalam pemerintahan Gap Baguna melalui sahabatnya seorang Muslim asal Jawa, Agama Islam mulai dipeluk baik oleh panguasa maupun penduduk (Alwi, 2005 297-298); 2). Menurut Varthema seorang pengelana Italia: Di Pulau Banda tidek ada raja atau pengua di sana tapi pulau ini dihuni di sana, mi pule satu masyarakat yang liar dan tidak beradab, kehidupan mereka tidak mengenal hukum dan pemerintahan Rumah-rumah mereka berbentuk kecil atau lebih tepat disebut gubuk yang terbuat dari kayu dan dibangun
diatas tiang. Perawakan mereka pendek, mereka tidak memaka penutup me maka penitup keplad rambut dibiarkan bertumbuh panjang dan dahi mereka lebar dan bundar. Warna kulit mereka agak gelap dan tinggi badan mereka rendah. Mereka menyembah berhala.... Mereka bodoh dan tidak kuat serta hidup secara berkelompok. Tanah mereka tidak menghasilkan buah-buahan lain selain pala. Buah pala setelah matang dipetik secara bersamasama. Pohon pala tumbuh secara sama. Poho pala tumbuh secara bebas tanpa dikultivasi. Selanjutnya tentang Ternate Ia menulis, Pulau ini sangat kecil walaupun dalam ukuran lebih panjang dari Banda. Penduduknya lebih parah daripada mereka di Banda. Seandainya mereka tidak memiliki perawakan sepert manusia, maka mereka sama sekali tidak berbeda dengan binatang. Warna kulit mereka lebih terang dan kawasan ini lebib sejuk. Pulau in menghas menghasilkan cengkih sebagaimana pulau-pulau kecil disekitarnya. Ketika cengkih sudah matang, masyarakat memukulnya dengan bambu sehingga jatuh berguguran diatas tikar yang telah lebih dulu ditebarkan diatas tanah dibawah pohon. Mereka menjual cengkih dengan harga dua kali lipat harga pala (Alwi $2005: 299-310$ ); 3). Franciscus Xaverius yang datang tahun 1546 melukiskan bahwa penduduk puru-pulau ini sangat pendu pul pun biadab dan sana sekall tidak dapa dipercaya. Kulitnya sawo matang dan pada hitam. ... Ada daerahdaerah yang penduduknya sering makan dagingnya sendiri(Keuning, 1977: 16 - 17); 4). ...kehidupan di perkampungan Maluku sangat membosankan. Tidak ada aktivitas penting apapun selain pembuatan perahu di pantai dan mencari ikan. Perairan di sekitar pulau-pulausan. kaya akan ikan du biota laut lo sehingga tidak ada seorangpun yang ingin berlelah pergi berburu ke hutan lahan tidak pernah diolah, kecual mereka membuat kebun-kebun kecil yang ditanami sayur dan kelap dan buah-buahan untuk keperluan keluarga sehari-hari. Keuntungan yang diberikan alam kepada Maluku adalah pohon sagu, yang bukan saja menyediakan bahan makanan tetap juga bahan kebutuhan lainnya seperti atap dan lainnya. Dalam setahun mereka disibukkan hanya beberap minggu untuk memanen eberap Panen cengih melibatk cengkih. Panen cengkih melibatkan laki-laki dan perempuan serta anak-anak. Laki-laki dewasa dengan bamb panjang memukul tangkai cengkih untuk menjatuhkannya ketanah lalu dikumpulkan sedangkan anakanak memanjat ke atas puncak pohon, meraih cabang-cabang kecil yang tidak dapat dijangkau dari tanah. Tenaga yang dikeluarkan untuk memanen dan menjemur pala, tidak lebih bert dari cengkih. Bagi pendudu Maluku, tanah, pengusahaan lahan, laut termasu ikan didalamnya milik satu desa adalah juga milik masyarakat des tersebut secara bersama. Artinya setiap penduduk desa berhak mengusahakan sebidang lahan untuk kebunnya dan mencari ikan dilau mana saja (Alwi, 2005 303-305).

Gambaran oleh penulis Eropa termasuk Xaverius tentang kehidupan orang diluar Eropa yang layaknya bukan manusia bahkan pandang Orang Eropa terhadap Orang Pribumi. Hal ini berbeda dengan informasi Rijali sebagai seorang Penulis Pribumi. Walaupun demikian, dari keterangan yang diberikan penulis-penulis tersebut terutama Rijali dapat memberikan gambaran umum tentang keadaan penduduk Maluku saat itu, bukan saja Ternate dan Banda tetapi juga pada daerah-daerah penghasil cengkih lain juga lahan tidak pernah dian rusa. Lahanpagi pe duduk Maluku, tank. mirip dengan binatang merupakan cara

demikian.Ternyata Orang Maluku saat itu mampu mengambil alih berbagai pengetahuan dan teknologi dari pedagang asing sehingga mampu meningkatkan kualitas hidup mereka.

\section{Maluku Dalam Percaturan Perdagangan} Internasional

Keterlibatan Orang Maluku dalam percaturan Perdagangan Internasional dan perjumpaan dengan berbagai pedagang asing Jawa, Cina, India, Arab dan Persiatelah berjalan sejak permulaan abad XIV. Perjumpaan in telah membawa perubahan dalam peradaban Orang Maluku, dimulai dari Istana dan Rumah-Rumah para pemimpin (Sultan dan Raja-Raja Kecil). Dari para pedagang asing ini para Sultan dan raja-raja memperoleh pengetahuan tentang: agama, perdagangan, pelayaran maupun berbagai teknologi baru. Mereka mampu mengakumulasi keuntungan mereka dari penjualan cengkih sehingga memperoleh kekayaan yang berlimpah dan dengan demikianmereka dapat membangun istana, membayar tentara, pelayan dan membiayai pembuatan kapal-kapal untuk pelayaran, perdagangan dan penaklukan. Kehidupan mewah mulai lahir melalui pengumpulan benda-benda berharga yang kemudian dianggap keramat.

Gambaran tentang keberadaan dan penampilan seorang Sultan pada tahun 1521 dilukiskan oleh Pigafetta demikian:

Raja dengan perahunya mendekat kapal-kapal kami.... ia duduk dibawah tirai sutra yang melindunginya dari semua arah dan terik matahari. Dihadapannya duduk seorang putranya dengan memegang tongkat kerajaan dan dua orang lagi memegang dua kendi emas untuk menyirami tangannya dan dua orang yang lain memegang dua kotak tempat sirih pinang. Pada saat itu Ia memakai kemeja yang terbuat dari jenis kain yang amat halus berwarn putih, ujung-ujungnya dibordir denge pur dan dibagion dalandis puring sepotong kain panjang dari dada hingga tanah. Ia bertelanjang kaki, kepalanya dililit sepotong kain sutra dan di 
atasnya dihiasi berbagai sejenis bunga (Alwi, 2005: 325-326).

Ternyata kehidupan para pemimpin Maluku saat kedatangan Pigafetta sangat berlainan dengan gambaran tentang kehidupa penduduk Maluku yang diberikan oleh Rijal dan penulis Eropa sebelumnya.

Rupanya perdagangan Internasional rempah-rempah telah melahirkan SultanSultan yang kaya dan agung dan tentu in tidak berbeda jauh dengan Raja-Raja di Banda, Ambon, Seram dan Lease. Pad tahun 1512 Portugis tiba di Banda setelah menguasai jalan dagang kedaerah rempahrempah melalui alur Timur mengitari Tanjung Harapan. Alfonso de Albuquerque lah yang merintis jalan ke pulau rempah-rempah setelah ia menaklukan Goa tahun 1510 dan kemudian Ia menaklukkan Malaka tahun 1511 yang merupakan basis penting dan pusa perdagangan Asia Tenggara. D'Albuquerque kemudian mengirim Kapten d' Abreu un mencari pulau rempah-rempah. Ekspedis ini diikuti 3 kapal dan dipandu oleh seorang yang bernama Kapten Ismail, Kapal kedua dikomandoi Kapten Ferdinand Magellan dan Kapal ketiga oleh Kapten Fransisco Serrao (Alwi, 2005: 312).Pada tahun 1511 mereka meninggalkan Malaka dan tiba di Banda Besar (Lontor) tahun 1512 kemudian mereka mengisi kapal-kapalnya dengan pala dan cengkih lalu kembali ke Malaka. Dalan perjalanan itu Serrao terjerat dalam badai dan terdampar di Pulau Lusipara. Dalam keadaan demikian Serrao dan pasukannya diserang oleh bajak laut yang dapat dikalahkan oleh Serrao. Kapal pembajak ini dirampas untuk digunakan. Akhirnya mereka tiba di Hit (Pulau Tiga) tahun 1512. Mereka diterima dengan baik oleh penduduk yang berharap dapat menjadikan mereka sekutu potensial.

Kabar tentang para pendatang baru yang menguasai berbagai ilmu pengetahuan menggerakkan Sultan Ternate Bolief dan Sultan Tidore Almanzor yang sedang bermusuhan terutama dalam perebutan kekuasaan untuk menguasai Seram, Ambon dan Lease, berlomba mengirim utusan untuk mengundang Serrao ke kerajaan mereka di Utara. Utusan Ternate Pangeran Juliba tiba lebih awaldan Portugis menerima untuk ke Ternate. Sultan menjadikan Serrao sebagai orang kepercayaan dan penaseha utamanya, satu penghormatan yang belum pernah diberikan kepada siapapun juga. Pada tahun 1513 Portugis membuka satu pos dagang di Ternate dan satu lagi di Bacan (Alwi,2005: 315 dan Amal, 2010: 22-23). Dengan demikian lahirlah satu alur dagang Ternate -Malaka -Goa -Lisabon.

$$
\text { Sebaliknya Tidore tidak tinggal diam }
$$

dalam mencari sekutu baru menghadapi Ternate dan Portugis. Bertepatan dengan itu pada tahun 1521 Magellan (Spanyol) melalui jalur barat tibadi Filipina dan ekspedisiini dilanjutkan oleh Del Cano dan berhasil tiba di Tidore (Alwi, 2005: 325). Sultan Tidore Almanzor berhasil membujuk Spanyol untuk mau bersahahat dan berhubungan dagang dengan mereka. Sultan sepaka untuk membuka sebuah pasar di dara agar pedagang Spanyol dapat berdagang dan membeli (barter) cengkih. Pada saa ini sepotong kain merah dengan kualitas yang tidak begitu bagus, pedagang Spanyol menerima satu bahar (550 pon) cengkih, untuk 50 pasang gunting bernilai satu bahar cengkih, untuk 3 gong dua bahar cengkih, Setelah kapal Spanyol (Victoria) penuh dengan muatan cengkih maka kapten Del Cano berlayar kembali ke Spanyol dengan meninggalkan 54 orang Spanyol sesuai permintaan Sultan untuk menjadi penasehat, melanjutkan perdagangan dan menyaing Portugis di Ternate. Persaingan ini berjalan sampai terusirnya Portugis dariTernate karena pembunuhan atas Sultan Khairundi benteng Gamlamo oleh Gubemur De Mesquita (Portugis) tahun 1570. Pada tahun 1606 Spanyol menyerang dan mengalahkan Sultan Saidi dari Ternate.Di sisi lain, Belanda sejak tahun 1607 sudah bersekutu dengan Ternate tetapi baru tahun 1663 berhasil mengusir keluar Spanyol dari Benteng Gamlamo.
Maluku sebagai poros perdagangan internasional rempah-rempah telah menjadi arena persaingan bukan saja antara PemimpinPemimpin lokal, tetapi juga antar pedagang Pemimpin lokal, tetapi juga antar pedagang
bangsa asing, terutama bangsa Eropa. Konstelasi politik regional yang demikian, telah melahirkan persekutuan-persekutuan antara kekuatan asing dengan para pemimpin lokal yang didasarkan atas pertimbangan pengendalian dan penguasaan perdagangan rempah-rempah.

Di Banda, sebelum pedagang-pedagang Eropa tiba, perdagangan rempah-rempah dilakukan dengan cara barter yaitu ditukar dengan beras dari Jawa,barang pecah belah dan gong dariCina, tekstil dari Gujarat dan alat-alat lain dari Malaka, juga ditukar dengan emas dan perak. Rempah-rempah Banda dibeli oleh pedagang-pedagang Jawa, Melayu, Cina dan Arab lalu dikapalkan kembali keTeluk Persia, diangkut oleh para kalifah ke laut tengah dan disebar melalui Konstantinopel (Istambul), Genoa atau Venecia. Pada saat ini di Maluku kota-kota dagang yang telah tumbuh dan berada dalam satu alur pelayaran adalah dari Malaka Jawa - Banda - Hitu - Ternate dan Tidore dan pelayaran sebaliknya akan juga mengambil jalur yang sama. Dengan demikian daerah ini merupakan daerah dengan kesibukan perdagangan yang luar biasa pada zamannya.

Pedagang-pedagang Cina sudah melakukan perdagangan dengan orang-orang Banda 600 tahun sebelum Portugis tiba tahun 1512 dan pedagang-pedagang Moro (Arab) telah berdagang dengan Banda tahun 1400. Pada tahun 1512, Portugis dibawah pimpinan Antonio de Abreu membeli bukan saja pala sebagai tanaman khas dan satusatunya di dunia tetapi juga cengkih yang diperoleh dari pedagang-pedagang regional yang membelinya dari Ternate dan Tidore. Hal tersebut menandakan Banda juga sudah menjadi pusat perdagangan rempah-rempah.

Menyusul Portugis, Pedagangpedagang Belanda tiba di Banda tahun 1599. Untuk dapat melakukan perdagangan dengan
Banda maka Belanda menyetujui syaratsyarat yang dikemukakan oleh para Orang Kaya Banda sebagai berikut:

1. Belanda diminta memberikan hadiah kepada Orang Kaya

2. Membayar upeti kepada syahbandar (Kepala Pelabuhan)

Maka perdagangan barterpun dimulai. Hadia yang diberikan Belanda pada Orang Kaya berupa: cermin, pisau, gelas kristal, beludru merah dan meriam kecil serta bahan-bahan mesiunya. Kemudian dua pos dagang (Loji) didirikan oleh Belanda (van Heemskerk) dan menugaskan para pedagang Belanda untuk mengelolanya dan mulai melakukan tawar menawar

Menyusul Belanda, Pedagang Inggris tiba di Banda (Pulau Run) tahun 1602 dan kemudian oleh Ratu Elizabeth I, Pulau Run dimasukkan sebagai bagian dan United Kingdom (Kerajaan Inggris) yang terdir dan England, Wales, Skotlandia, Irlandia dan Run. Inggris membangun pos dagang di Run dan Pulau Ai. Terjadilah persaingan harga rempah-rempah yang menguntungkan para Orang Kaya Banda. Untuk itu Beland mengikat orang kaya Banda dengan perjanjianperjanjian yang lebih mengikat terutama tentang perdagangan rempah-rempah dan dipaksa mendapat hak membangun benteng di Pulau Neira.Terjadi perlawanan terhadap Belanda yang dilukiskan oleh Des Alwi

(2005 : 46-48) demikian :

Pada tanggal 22 Mel 1608 pada tempat perundingan yang telah disetujui (antara Orang Kaya Lontor dengan Belanda) Verhoeven diserang dan dibunuh bersama 40 orang anak buahnya. ...Belanda tidak berani turun dari kapal dankeluar dari benten (Nassau) sehingga terjad kelaparan dan mereka terjad pap rimaka La saja yang bisa Himakn. Sampai Laksamana Hoen mengirim beberapa ekspedisi membawa makanan dan untuk menghukum 
masyarakat Banda,mereka me m porakporandakan perkampungan di pesisir dan perkanpungand pesisir da menbar perate serta memperoleh banyak barang rampasan. ....Ak hirnya pada 13 Agustus 1609 ditanda tangani sebuah pakta penjanjian yang berisi butir-butir sebagaimana lazimnya yang menyangkut, agama, monopoli perdagangan Dengan beberapa butir tambahan yaitu: 1). Setiap kapal yang masuk harus membuang sauh dihadapan benteng Belanda dan tadapa benteng Belaks dan terbuk jertur diperiksa; 2). Seluru jalur pelayaran antar pulau harus mendapat izin dari Belanda dan tidak ada seorangpun yang boleh berdiam di Neira tanpa izin Belanda; 3). Untuk selamalamanya Neira menjadi milik Belanda.

Perjanjian ini tidak mencakup Pulau Run dan Pulau Ai dimana berkedudukan Orang Inggris. Biarpun perjanjian sudah ditandatangani oleh para Orang Kaya tetapi terjadi berbaga pelanggaran karena tidak ditaati dan para pedagang regional terus beroperasi membeli fuli dan pala dan menjualnya kembali pada pedagang Inggris atau dikirim ke Banten untuk dijual ke Portugis atau ke pasar-pasar gelap yang mulai berkembang di Makassar. Karena monopoli Belanda selalu tidak ditaati oleh para Orang Kaya dan didukung oleh rakyatnya maka satu-satunya jalan yang diambil Belanda adalah menaklukkan secara penuh Banda dan menghukum dengan berat para Orang Kaya termasuk rakyatnya yang melawan dengan pembuangan atau pengusiran mereka keluar Banda. Strateg ini baru dapat terlaksana tahun 1621 setelah ditandatanganinya perjanjian dagang antara Inggris (East India Company) dan Belanda (VOC) pada tahun 1619 tanggal $17 \mathrm{Juli}$, bahwa kedua Kerajaan tersebut sepaka mengampuni dan melupakan perselisihan mereka dimasa-masa lampau. Pada tahun
1621 Jan Pieterszoon Coen bertolak dari Batavia menuju Ambon dan terus ke Banda (Nasau) dengan armada 13 kapal besar, 3 kapal kecil, 6 perahu layar dengan pasukan 1.665 Orang Eropa, 250 Garnisun Banda dan pendayung 286 orang hukuman (Jawa) dan pemikul barang, serta 80 - 100 orang tentara Jepang. Hal itu merupakan ekspedisi paling besar untuk Banda.

Peristiwa penaklukan dan penghacuran Banda dipaparkan sebagai berikut:

Coen menaklukkan Banda dengan kekerasan dan mengirim secara paksa para pemimpin dan rakyatnyakeluar daerah Banda. Pengejaran terhadap penduduk dilakukan sampai gununggunung apa saja yang ditemukan dimusnahkan. Terjadi ditarianpenduduj secara besarpelarianpenduduj secara besarbesaran meninggalkan Banda. Ada yang ke Seram Timur, ke Kepulauan Kei (kurang lebih 2000 orang) dan sebahagian lagi 883 orang dikirim dengan cara paksa oleh Coen ke Batavia. ...Kepulauan Banda Neira dibagi menjadi 37 kavling. Kavlingkavling inilah yang dinamakan Perk maka lahirlah istilah perkenier untuk mereka yang mengolahnya. Untuk Pulau Run yang milik Ingris Pula Run yang milik Inggrs, Belanda menukarkannya dengan pulau Nieuw Amsterdam sekarang Manhattan dengan Inggris (Alwi, 2005: 72 -84)

Demikianlah Kepulauan Banda dikosongkan dari penduduk aslinya dan dikuasai VOC secara mutlak. Sebagai pekerja perkebunan, Belanda mendatangkan dari luar.

Pada abad XV, Seram, Ambon dan Lease telah memiliki hubungan dagang dengan dunia luar karena letaknya yang strategis antara antara jalur rempah-rempah Ternate - Tidore - Banda, meskipun pohon cengkih tanaman terutama dari Maluku pada saat itu masih belum atau belum lama dipindahkan kesana. Pada tahun 1512 ketika Francisco Serrao tiba di Hitu. Pada saat itu terjadi peperangan antara Ternate dan
Tidore untuk menguasai wilayah ini. Ternate bersekutu dengan Uli Lima dan Tidore dengan Uli Siwa. Sejak saat itu pengelompokan atas Siwa dan Lima menjadi kabur karena yang Siwa dan Lima menjadi kabur karena yang
dikalahkan dipaksa untuk mengganti Uli bahkan berganti Agama. Portugis membantu Ternate yang saat itu bersekutu dengan Hitu (Uli Lima) mengalahkan Tidore. Sebagai imbalannya, Portugis mendapat tempat untuk berdagang di Ternate dan di Hitu. Pada tahun 1525 mereka mendapat izin membuat sebuah rumah dekat Negeri Mamala sekarang. Tetap ketika orang Portugis ingin membangun sebuah benteng dan membuat peraturanperaturan sendiri, mereka ditentang oleh para pemimpin Hitu (Empat Perdana). Oran Hitu meminta bantuan dari Ratu Japara di pulau Jawa dan mengusir orang Portugis melalui daratan ke Lei timor (Uli Siwa) Sejak itu mulai terjadi pengkristenan orang Lei Timor dan pada tahun 1547 sudah ada 7 perkampungan yang menyebut dirinya Kristen (Keuning, 1977: 16).

Pada tahun 1590 armada Belanda dibawah pimpinan Jacob Cornelisz van Neck dan Wybrant Warwyck tiba di Hitu. Belanda diterima oleh pemimpin Hitu dengan sangat gembira dan diminta membantu Hitu menyerang Portugis. Tahun 1600 van der Haghen membantu Hitu dan Jawa untuk merebut benteng Portugis di Ambon tetap tidak berhasil dan baru dapat ditaklukan pada tahun 1605, dengan penyerahan Benteng Portugis (Kota Laha) di Ambon oleh de Melo kepada van der Haghen yang kemudian benteng itu berganti nama menjadi Kasteel Victoria (Benteng Kemenangan).

Sebagian besar orang Portugi diperintahkan untuk meninggalkan Ambon. Pada bulan Februari van der Haghen membuat pejanjian dengan KapitanHitu dan Raja-Raja kecil lainnya. Kalau dicermati dengan baik inti dari perjanjian-perjanjian yang dibuat baikoleh Belanda dengan Ternate, Tidore, maupun dengan Pimpinan Uli dan Raja-Raj Kecil di Maluku lainnya (Banda, Seram, Ambon dan Lease) mengandung tujua yang sama yaitu:1). Mempertahankan hak monopoli; 2). Pengendalian harga rempahrempah; 3). Penguasaan atas tindak tanduk para pemimpin; 4). Saling mebantu dalam memerangi musuh bersama; 5). Setiap orang akan hudup sesuai agamanya masingmasing dan 6). Bersedia membantu penguasa Belanda dalam berbagai pekerjaan apabila dibutuhkan.

Orang Hitu (Uli Lima) merasa berterima kasih akan apa yang dialaminy sebagai satu pembebasan, tidak seperti orangorang Leitimor (Uli Siwa) dan Lease yang dicaplok begitu saja oleh Belanda.Pada tahun 1610 Ambon telah tumbuh menjadi pusa kekuatan Belanda di Maluku. Berbeda dengan orang-orang Hitu, orang-orang Leitimo harus melakukan berbagai pekerjaan untuk Belanda seperti; tembok-tembok benteng dipertinggi, penggalian parit, pendirian bangunan-bangunan baru dan sebagai pendayung kora-kora. Semua pekerjaan dilakukan tanpa menerima pembayaran, bahkan makanan harus ditanggung sendiri. Hal tersebut membuat orang-orang Soya, Ema dan Kilang rnembangkang untuk bekerja dan inilah perlawanan yang pertarna dari orang-orang Leitimor. Sementara itu Negeri Hutumuri yang tinggal dekat Benteng kembali lagi ke negeri asalnya dan tidak lagi tunduk pada Belanda.Hutumuri diserbu dengan kekuatan 80 orang Belanda dan 1000 Orang Ambon. Perlawanan Hutumur dapat dipatahkan dan 350 orang laki-laki, perempuan dan anak-anak dibawa pulang sebagai tawanan. Kemenangan ini membua orang Leitimor merasa segan untuk mebuat perlawanan lagi pada Belanda.

Perjanjian yang telah dibua antara Belanda dengan Para Pemimpin di Seram, Ambon dan Lease ternyat dilanggar. Untuk menegakkan monopli maka Belandamelakukan Prang Hongi yang dikisahkan demikian:

Karena Belanda tidak mampu lagi untuk mengontrol perdagangan antara penduduk dan pedagang Asia maka dilakukanlah perang Hongi terutama di daerah Hitu dan 
Huamual yaitu pemusnahan terhadap tanaman cengkih dan penduduk yang dilakukan setahun sekali. Dalam perang ini digunakan kora-kora 30 sampai 40 buah, yang dilayani oleh 3000 atau lebih pendayung Ambon, Leitimor dan Lease. Dalam pelayaran ini sering terjadi peperangan dengan pedagang Jawa dan Makassar di laut. Hal ini mengakibatkan mereka menghindari Hitu dan mereka berlabuh di pulau-pulau kecil atau masuk di sungai-sungai di Seram Barat. Cengkih nanti diangkut dari Hitu untuk mereka di sana. Untuk memblokade perairan sulit dilakukan Kompeni karena kekurangan kapal tetapi mereka telah berhasil merintangi perdagangan bebas. Harga bahan pokok meningkat tajam: beras dan 20 real sepikul menjadi 50 sampai 60 real; barang-barang tenun dan 10 real menjadi 30 sampai 40 real (Keuning, 1977: 31)

Sebagai balasannya, penduduk memboikot membeli barang-barang Belanda. Di Huamual daerah yang kaya akan cengkih orang mulai menyerang Belanda. Pedagang Indonesia tetap berdatangan ke sana dan sebagian besar hasilnya diangkut oleh mereka. Belanda (van Speult) menganggap hanya tindakan-tindakan dengan kekerasan sajalah yang dapat menyelamatkan pardagangan mereka yaitu dengan menghancurkan secara besar-besaran perkebunan cengkih di Seram dan menanam secara besar-besaran di Leitimor dan Lease dimana kompeni lebih berkuasa disitu untuk monopoli. Pada tahun 1625 rencana ini dapat dilaksanakan dengan pelayaran Hongi. Setiap pohon cengkih, kelapa dan sagu ditebangi atau dikupas kulitnya, perahu-perahu yang dijumpai di tepi pantai dan sungai dirusakkan sehingga tidak dapat dipakai lagi. Pelayaran Hongi in berlangsung 6 minggu lamanya dan penduduk kehilangan 65.000 pohon cengkih dan banyak lagi harta benda lainnya (Keuning, 1977 :35-36). Pertahanan cengkih Huamual belum dapat dipatahkan dan kapal dagang dari Makassar makin banyak bukannya makin berkurang, mereka membayar harga mereka bekerja dengan panjar modal dari pedagang Inggris, Denmark dan Portugis. Pedagang Makassar ikut juga menanggung beban biaya sebagai resiko dalam perdagangan ini.

Perlawanan demi perlawanan timbul akibat Hongi dan monopoli dan bukan datang dari Huamual saja tetapi Hitu dan beberapa Negeri di Lease juga telah membangkang terhadap Belanda. Hal ini memang dimungkinkan karena panduduk mengetahui dari pedagang Makassar sebenarnya berapa nilai cengkih yang seharusnya mereka peroleh. Kekacauan dan peperangan ini berlangsung terus dari tahun 1620 sampai tahun 1656 dengan munculnya berbagai tokoh pejuang silih berganti memimpin rakyatnya menentang Kompeni seperi di Huamual (Seram Barat) oleh Kimelaha Hidayat 1620-1624; Liliato 1624-1638; Kimelaha Luhu 1638-1646 dan Madjira 1643-1656; di Hitu para Kapitan Hitu terutama Kakiali 1633-1643 dan Telukabessy 1643-1646 mereka dibantu oleh Makassar yang secara teratur mengirim bantuan dalam setiap peperangan. Pada tahun 1635 tiga belas Negeri di Leitimor yang telah ditarik turun mendiami sekitar Benteng menghilang kembali ke negeri mereka masing-masing dipegunungan dan hanya penduduk negeri Nusaniwe saja yang tetap bertahan. Alasan dari mereka meninggalkan kediamannya di sekitar Benteng karena Belanda telah memperlakukan mereka (rakyat maupun pemimpinnya) sebagai budak.

Satu demi satu para penjuang di Ambon dan Lease dilumpuhkan. Leliato dibawa ke Batavia dan dihukum pancung pada tahun 1644, Luhu dihukum mati (pancung kepala) tahun 1643 bersama ibunya, saudara perempuannya dan saudara laki-laki tirinya di Benteng Victoria. Kakiali dibunuh dan pada 16 Agustus 1643, Telukabessy dihukum penggal kepala tahun 1646, sedangkan Rijali dapat meloloskan diri ke Makassar dan disana ia menulis bukunya "Hikaya Tanah Hitu". Setelah kekalahan Telukabessy, van Diemen membuat perubahan besar dalam struktur masyarakat Maluku. Semua perkampungan di gunung diturunkan ke pantai untuk mempermudah pengawasan. Hena atau Aman sebagai satu kesatuan genealogis, teritorial, religius, rakyatny dipisah-pisahkan. Di Hitu, fungsi dari Empa Perdana dihilangkan dengan demikian setiap Aman atau Hena (Negeri) berdiri sendirisendri dengan seorang Raja pada masingmasing negeri.

Kimelaha Luhu Madjira mengadakan perlawanan terhadap Belanda dan dapat dipatahkant ahun 1656 dan ia melarikan diri ke Makassar. Di Leitimor Jan Pays yang baru kembali belajar di Nederland berkomplot dengan Madjira untuk menghalau Belanda. Ia ditangkap kemudian secara diam-diam dipenggal dan tubuhnya dipertontonkan pada masyarakat untuk menakut-nakuti. Bersamaan dengan kekalahan Madjira tahun 1656. Huamual dibumihanguskan untuk kedua kalinya yang dilukiskan sebagai berikut:

Atas perintah de Vlaming seluruh Huamual dikosongkan dan 12000 penduduk yang berasal dari daerahdaerah yang subur dipindahkan ketempat lain. Orang-Orang yang beragama Islam ditempatkan di Hitu dan mereka kehilangan Orang Kayanya yang ditempatkan sebagai sandera di Benteng. Orang-orang disebarkan di berbagai kampung di Hitu sehingga ikatan-ikatan kekerabatan menjadi pecah. Ayah dan anak, dua saudara misalny di tunjuk tempat tinggal sejauh mungkin yang satu dan yang lain Orang-Orang Kristen dan Kafi di Huamual mengalami nasib yang sama; mereka diharuskan pindah ke Leitimor dimana mereka disebar diantara kampung-kampung orang Kristen. Pengungsian secara besar-besaran ini dilakukan pad 6 Maret 1656. Juga pulau-Pulau kecil Kelang, Ambalauw dan Buano dikosongkan dari orang-orang dan ditempatkan di Manipa. Tokohtokoh merekapun ditempatkan di Ambon dekat Benteng. Orang-Orang
Ihamahu (catatan penulis: ini lebih tepat orang Iha) Islam dari Saparua di tunjuk Seram (Huamual) sebagai tempat tinggalnya. Mereka ini tidak diperkenankan pulang ketempatnya masing-masing. Akhirnya pada tahun 1657 Orang-Orang Kaya yang ditempatkan di Benteng dengan keluarganya sejumlah 282 orang dibuang ke Batavia untuk selamalamanya. Huamual dengan pulaupulau kecil yang telah dikosongkan, dimusnahkan dengan sempurna. Kampung-kampung dibakar, pohonpohon cengkih dikupas kulitnya dan ditebangi juga hutan-hutan sagu sedapat mungkin dirusakkan. Tanah itu menjadi kosong dan sunyi. (Keuning, 1977:54.57).

Mulai saat itu (tahun 1656) hanya Pulau Ambon dan Lease yang dapat menanam cengkih. Tiap-tiap tahun akan diadakan pelayaran Hongi untuk memusnahkan semua tunas cengkih dan pohon-pohon yang telah tua yang mungkin masih ada diluar Ambon dan Kepulauan Lease. Belanda menggunakan kuota penanaman dimana kalau permintaan pasar tinggi maka penduduk diperintah untuk menanam beribu-ribu anak cengkih da apabila berlebihan akan dimusnahkan. Masa perlawanan di Ambon dan sekitarnya dapa diakhiri oleh Belanda.

Munculnya Thomas Matulessy pada tahun 1817 dengan pemberontakannya adalah sebagai jawaban ketidak-puasan terhadap penjajahan Belanda. Tapi upaya membebaskan diri dari penjajahan Belanda masih jauh dari harapan karena perjuangan ini juga dapat dilumpuhkan. Kemerdekaan yang didambakan itu akhirnya tiba juga pada tanggal 17 Agustus 1945.

Dari Monodualistis Ke Dualistis Oposisi

Fakta Sejarah memperlihatkan bagaimana Perdagangan Internasiona rempah-rempah telah memperkenalkan Maluku ke seantero dunia. Perjumpaan dengan berbagai bangsa asing, telah membawa sejumalah perubahan. Disatu sisi menghasilkan kemajuan dalam penguasaan 
berbagai pengetahuan baru dan teknologi. Disisi lain, mendatangkan kesengsaraan akibat dihancurkannya secara sistematis berbagai sistem nilai budaya masyarakatnya. Kebudayaan orang Maluku (Seram, Ambon, Lease, Aru dan Kei) dibangun diatas sistem nilai budaya monodualistis. Yang dimaksud dengan sistem nilai budaya monodualistis adalah: kebudayaan yang menganggap bahwa satu kesempurnaan adalah hasil dari perpaduan dua yang berbeda. Sistem nilai budaya monodualistis tercermin dalam kosmologi Uli Siwa dan Uli Lima. Kelompok Siwa dan Lima memandang kosmos mereka sebagai satu perpaduan antara dua elemen berbeda yang saling tergantung, saling melengkapi dan saling membutuhkan yaitu Langit yang dipersonifikasikan sebagai Laki-Laki (Bapak) dan Tanah sebagai Perempuan (Ibu). Langit disapa sebagai Upu Lanite (Bapak atau Tuhan Langit) dan Tanah sebagai Ina Ume (Ibu atau Tuhan Tanah). Klasifikasi Langit dan Tanah atas Laki-Laki dan Perempuan telah menjadi dasar klasifikasi terhadap berbagai elemen yang berkaitan dengan kehidupan keadatan dan religi mereka. Gunung (laki-laki) x Pantai (Perempuan); Lautan (Laki-laki) $x$ Daratan Perempuan); Matahari (Laki-Laki) x Bulan (Perempuan), Atas (Laki-Laki) x Bawah (Perempuan) dan lainnya. Atas dasar pandangan inilah Siwa mengidentifikas diri mereka sebagai laki-laki dan Lima perempuan.

Klasifikasi ini dapat dijumpai juga pada konstruksi Baileu (Rumah Adat Negeri). Baileu Uli Siwa berbentuk panggung dan Uli Lima rata dengan permukaan tanah.Bagian dalam rumah Baikeu secara horisontal terbag dua yaitu baigian gunung (laki-laki) dan bagian pantai (perempuan), secara vertikal bagian tanah atau lantai (perempuan) dan bagian langit atau bumbungan (laki-laki). Luma Tau pembentuk Aman atau Hena masing-masing mempunyai kedudukan dalam Baileu yang didistrubusi sesuai dengan status dan fungsinya. Ada status dan fungsi Luma Tau yang di kategorikan sebagai perempaun dan menempati belahan perempuan (pantai) 列 dan fungsi Luma Tau yang berkedudukan di bagian laki-laki (gunung). Perbedaan, lambang-lambang dan adat istiadat antara Siwa dan Lima, tidak memberi kemungkinan anggota kedua kelompok ini untuk tinggal bersama dalam satu Hena atau Aman. Segregasi pemukiman merupakan hasil dari pandangan Monodualistis Siwa-Lima (Laki-
Laki - Perempuan) untuk kesempurnaan kosmos mereka.

Di Kepulauan Kei. Ur Siuw diidentifukasi sebagai perempuan. Dia dibentuk oleh seorang perempuan (Ditsakmas) melui pemotongan seekor (Ditsakmas) melalui pemotongan seeko kecil) dan dibagi kepada 9 Ohoi, dipihak lain Lor Lim sebagai laki-laki karena dibentuk oleh seorang laki-laki (Jangra) yang memotong ikan Paus di negeri Ler Ohoilim (Kei Besar). Dalam sistem nilai budaya kerbau (daratan) digolongkan sebagai perempuan (dan paus (lautan) sebagai laki-laki. Pandangan ini memberi makna bahwa kosmos bukan dibentuk oleh perpaduan antara sembilan dan lima, tetapi oleh elemen perempuan dan lakilaki. Saling melengkapi dalam mewujudkan keharmonisan dan kesempurnaan antara Siuw dan Limdapat dilihat dalam melahirkan Hukurn Larvul Ngabal (Larvul= Darah merah, Ngabal= Tombak dari Bali). Hukum Larvul Ngabal Pasal 1 s/d 4 dicetuskan oleh Siwa dan Pasal 5 s/d 7 ditentukan oleh Lima. Kedua hukum ini digabung menjadi 7 pasal dan dijadikan sebagai hukum dasar bersama.

Aku ada untuk kamu dan tanpa kamu aku tidak berarti. Inilah model keseimbangan dan keharmonisan dalam tata nilai budaya masyarakat monodualistis. Pandangan ini merupakan pengakuan adanya perbedaan tapi saling membutuhkan. Masing-masing berhadapan sebagai dua yang berbeda tetapi tidak untuk memusnahkan karena kesempurnaan dan keharmonisan kosmos justru mengharuskan keberadaan keduanya $($ laki-laki $=$ siwa dan perempuan $=$ lima $)$ Dalam kenyataannya budaya monodualistis
Siwa-Limatelah mengalami pergeserannilai karena masuknya nilai-nilai baru yang dipaksakan melalui kekerasan, penaklukan dan penguasaan.Sejauh mana nilai-nilai dan penguasaan. Sejauh mana nilai-nilai monodualistis bergeser akibat berbenturan
dengan nilai-nilai baru, dapat dilihat dalam dengan nilai-nilai

Persaingan antara Ternate dan Tidore pada abad XVI untuk menguasai Seram, Ambon dan Lease dan menguasai perdagangan cengkih disini telah memperkenalkan sistem cengkih disini telah memperkenalkan sistem dan ingin penyeragaman. Ini berbeda dengan sistem nilai monodualistis yang dianut oleh Siwa dan Lima yaitu harus adanya dua elemen yang berbeda (laki laki dan perempuan) dalam mencapai kesempurnaan. Dengan kekerasan Ternate dan Tidore mendorong Siwa dan Lima terlibat dalam persaingan dan peperangan antar keduanya dalam perebutan kekuasaan melalui penaklukan.Sistem nilai budaya baru diperkenalkan yaitu, ingin menguasai, ingin menaklukkan, ingin penyeragaman, dan ingin menempati kosmos sendiri dalam arti tidak mengingini adanya perbedaan dalam kosmos. Untuk mencapai ambisi itu, rakyat taklukan dipaksa berganti Uli, bahkan berganti agama. Mulai saat inilah agama mulai dipakai sebagai pembeda dan bukan lagi Uli atau Pata. Pada saat inilah pandangan monodualistis mulai bergeser pada pandangan dualistis-oposisi dalam sistem nilai budaya Orang Siwa-Lima.

Nilai-nilai baru yang diadopsi, telah menyeret kelompokSiwa dan Limadalam perang terbuka yang dimotori kesultanan Ternate dan Tidore. Konflik yang muncul bukan lagi diantara dua belahan yang berbeda yang selalu diikat oleh adat untuk menjaga keseimbangan kosmos, tetapi diantara dua belahan yang masing-masing ingin menguasai kosmos untuk dirinya sendiri, olehnya salah satu harus ditaklukkan bahkan bila perlu dimusnahkan. Dalam konflik ini hanya ada dua pilihan yaitu menghancurkan atau dihancurkan.

KehadiranOrangPortugis dan Belanda lebih memperkuat sistem nilai budaya dualistis-oposisi. Bukan saja terjadi pertentangan antara Siwa dan Lima tetapi juga antara sesama Siwa dan sesama Lima. Belanda berhasil merusak struktur dasa budaya mereka yang dibangun berdasarkan ikatan kekerabatan (genealogis, religius dan teritorial). Ikatan ini telah melahirkan dan membentuk solidaritas yang tinggi antar individu dan kelompok. Sehingga strategi apapun tidak mampu memisahkan dan memecah belahkan mereka kecuali dengan menghancurkan sistem nilai tersebut.

Orang Siwa dan Lima kehilangan identitas sistem nilai monodualistisnya, sebab perbedaan agama kemudian menjadi lebih menonjol dan telah dipakai oleh Belanda dan Ternate sebagai pembeda. Ada orang-orang Siwa Islam dan ada Orangorang Siwa Kristen begitupun sebaliknya Belanda dengan sistematis menghancurkan persekutuan-persekutuan adat dan struktur sosial melalui berbagai cara selain seperti yang telah dikemukakan di atas di antaranya:

1. Orang dipaksa atau dibolehkan untuk berganti Pata atau Uli atau Agama mereka. Pata atau Uli Siwa dan Uli Lima tidak dapat dipakai lagi sebagai identitas utama kelompok. Struktur pemerintahan pada Uli tingkat kedua dihapus dan Aman atau Hena berdiri sendiri-sendiri, memunculkan fanatisme Negeri karena hilangnya solidaritas Uli. Muncul istilah anak neger (istilah untuk penduduk asal satu negeri) untuk membedakannya dengan anak neger yang lain biarpun se-Uli.

2. Aman dan Hena (berdasarkan genealogis, religius dan teritori) diubah namanya menjadi Negeri dan diturunkan ke pantai. Negeri bukan lagi mutlak sebagai satu ikatan genealogisseperti Aman atau Hena. Orang Kaya, Patti dan Raja sebaga pemimpin ditunjuk langsung oleh Belanda sehingga menghilangkan hak dari Luma Tau Aman Latu atau Ina Latu dan Upu Latu untuk memerintah

3. Agama telah menjadi identitas penting dan ini terlihat pada segregasi Neger berdasarkan agama yang dianut. Agam telah dapat menghilangkan adat mengayau 
dan ini sangat penting, tetapi agama tidak mampu mempertahankan nilai keharmonisan dalam perbedaan sebagai penghuni satu kosmos yang sama.

4. Budaya kewirausahaan hilang bersamaan dengan ditegakkannya sistem monopoli. Tidak ada pedagang-pedagang besa Maluku yang lahir sejak itu. Orang melihat dunia dagang sebagal milik orang lain, ini dikuatkan dengan penggunaan istilah Orang Dagang bagi Orang luar yang bukan anak negeri.

5. Muncul budaya kekerasan dalam menyelesaikan berbagai masalah akibat keterlibatan masyarakat secara teratur dan terus-menerus selama beratus-ratus tahun dalam konflik antar mereka.

6. Sistem nilai monodualistis (berdampingan dalam perbedaan) tidak lagi menjad panutan Sistem nilai budaya orang Maluku.

\section{Zaman Pencerahan}

Masa-masa kegelapan di Maluku (Seram, Lease, Ambon) mendatangkan penderitaan bagi penduduknya. Mereka saling bermusuhan dan menghancurkan, tercera berai, baik dalam ikatan-ikatanberdasarkan kekerabatan, adat istiadat maupun persekutuan Uli. Peristiwa ini telah menyadarkan para pemimpin, tua-tua adat untuk kembal mengenal jatidiri mereka melalui pengenalan ulang nilai-nilai budaya dan sejarah asa usulnya. Para tua adat mulai mencari lagi kerabat-kerabat mereka yang terpisah oleh karena perbedaan agama atau dipisahkan dengan paksa oleh Belanda untuk kembali menjalin hubungan persaudaraan. Pengenalan diri kembali ini ternyata telah melahirkan ikatan-ikatan baru yang didasarkan asas persaudaraan (kekerabatan), persahabatan dan tolong menolong lintas Budaya, lintas Bahasa, lintas Negeri, lintas Uli, lintas Pulau dan lintas Agama sebagai peredam kekerasan antar sesama anak negeri Maluku dan adanya keinginan untuk hidup berdampingan secara damai dalam perbedaan.
Sistem nilai budaya baru ini dikenal dengan nama Bongso, Adi-Kaka,Gandong dan Pela.

$>$ Bongso (bungsu), adalah satu term kekerabatan (persaudaraan) yang menunjukkan status seseorang sebaga anak bungsu atau adik bungsu dalam satu keluarga batih. Anak atau adik bungsu dalam keluarga di Maluku adalah sosok yang disayangi. Masyarakat dua Negeri atau lebih yang terikat dalam ikatan Bongso saling menyapa satu dengan yang lain sebagai bongso. Makna yang terkandung dalam ikatan ini adalah kasih sayang antar sesama bongsolaiknya orang tua kepada anak bungsunya atau kakak terhadap adik bungsunya.

$>$ Gandong (sekandung), adalah satu Gandong (sekandung), adalah satu
term kekerabatan (persaudaraan) yang digunakan untuk menyatakan hubungan persaudaraan antar anak-anak yang lahir dan berasal dan satu kandungan (Ibu). Ada perbedaan jelas antara saudara sekandung dan bukan, dalam adat Maluku relasi antara saudara sekandung lebih erat dariselasi gerat darirelasi antar saudara yang bukan sekandung. Hubungan antara saudara sekandung selalu dalam suasana saling menyayangi, saling melindungi dan saling tolong menolong. Negeri-negeri yang terikat dalam ikatan gandong, akan saling menyapa gandong satu pada yang lain apabila bertemu,

$>$ Adi-Kaka (Adik-Kakak) adalah term kekerabatan yang digunakan oleh orang Maluku untuk menandai hubungan atau relasi antara dua orang atau lebih yang berkerabat baik dalam satu keluarga luas maupun batih dari garis ibu maupun ayah, dimana yang lebih tua dianggap sebagai kakak dan sebaliknya adik. Hubungan $a d i$ - kaka antara dua negeri merupakan hubungan kerabat (ikatan kerabat) yang saling menghormati, melindungi dan membantu.Anggota masyarakat negerinegeri yang diikat oleh ikatan adi-kakayang kaka akan menyapa negeri yang dianggap adik sebagai adidan sebaliknya kaka tanpa memandang perbedaan usia.

$>$ Pela adalah sejenis ikatan persaudaraan antara dua negeri atau lebih, Pengertian pela sebagai persaudaraan lebih luas cakupannya dari Bongso, Adi-Kaka dan Gandong karena tidak terbatas pada habungan-hubungan kekerabatan atau hubungan genealogis. Negeri-negeri yang terikat dalam ikatan pela berada dalam ikatan saling membantu, saling melindungi dan masyarakatnya saling menyapa Pela satu pada yang lain (Huliselan, 2005 : 238-239).

Uraian diatas memperlihatkan bahwa ada dua nilai persaudaraan yang dibangun dalam kebudayaan Maluku oleh pendukungnya untuk mengembalikan keharmonisan hidup dalam kosmos mereka melalui ikatan-ikatan Bongso, Gandong, Adi-Kaka dan Pela. Ikatan persaudaraan ini mengingatkan kita pada ikatan Luma Tau dalam satu Aman dan Hena sebagai satu ikatan genealogis yang telah dihancurkan Belanda.

Bongso, Gandong, Adi-Kaka dan Pela, ternyata telah mampu meredam nilai-nilai perbedaan, pertentangan dan permusuhan dan membangkitkan lagi nilai-nilai persaudaraan, kekeluargaan, kebersamaan, persatuan, saling rnenghormati, saling menghargai, saling mengasihi, saling mempercayai dan saling membantu. Bagaimana nilai kerukunan ini telah diwujudkan dapat kita lihat dari nilainilai tolong menolong untuk sama-sama membangun negeri melalui sumbangan tenaga maupun materi darinegeri-negeri yang diikat oleh ikatan-ikatan ini misalnya: dalam membangun Masjid, Gereja, Baileu dan lainnya. Lebih penting lagi bahwa sewaktu kegiatan tolong menolong atau panas pela diadakan, ada rumah-rumah khusus yang disediakan oleh negeri yang ber-pela kepada pela-nya yang berbeda agama untuk menjalankan ibadah di rumah tersebut. Inilah nilai hidup bersama dan saling menghargai akan agama masing-masing yang sangat tinggi nilainya dan tidak ada taranya.

Pada Kepulauan Kei kebersamaan dan hidup berdampingan dengan damai ini diwujudkan melalui sistem nilai budaya "Ain Ni Ain" (satu punya satu) yang mengandung makna kita semua adalah satu. Di Aru kebersamaan ini diwujudkan ma merikut: "uru siwa, uru lima sita kaka walikena, walikena-walikena sita kaka walikena" (Siwa-Lima orang bersaudara atau dengan kata lain berbeda tetapi tetap satu).

\section{Penutup}

Tidak dapat disangkal bahwa saat ni nilai-nilai pencerahan seperti nilainilai persaudaraan dalam perbedaan, nilai toleransi, saling menghargai da menghormati dipengaruhi kuat oleh nilai nilai baru karena: Pertama, sifat kebudayaa yang dinamis; Kedua, pengaruh eksterna yaitu pengaruh budaya global dan pemaksaan berbagai aturan oleh pemerintah demi penyeragaman. Untuk itu kedepan pilar-pilar budaya harus didirikan diatas Fondasi yang kokoh yang mengandung nilai-nilai budaya persaudaraan dan tolong menolong dalam bentuk yang lebih modern sesuai dengan tuntutan globalisme. Menghidupkan nilainilai ini adalah satu kebutuhan mendesak sebagai jawaban dari masyarakat yang majemuk dan pluralistik agar sama-sama dapat maju dalam perberbedaan menghadapi era baru.

Sebagai penutup munculdua pertanyaa berikut: 1). Bagaimana Orang Maluku dapat berperanlagi dalam Perdagangan Internasional seperti yang lalu menginga letaknya yang strategis? dan 2), Bagaiman hasil lautan dapat lagi menjadi komoditi andalan pengganti cengkeh dalam percaturan perdagangan internasional saat ini? Semuanya tergantung pada kesiapan Sumberdaya manusia Maluku saat ini dan kedepan. 


\section{DAFTAR PUSTAKA}

Andrews, B.A, P. Andrews, G. Loski, J. Tjia, J.S. Wimbish. 1996, Atlas Bahasa Tanah Maluku. Diedit oleh Taber. M. Pusat Pengkajian dan Pengembangan Maluku. Unpatti dan Summer Institute of Linguistics. Ambon: Universitas Pattimura.

Amal. AM. 2010. Kepulauan Rempah-rempah, Perjalanan Sejarah Maluku Utara 12501950. Jakarta: Kepustakaan Populer Gramedia.

Amal A. M. 2010, Portugis dan Spanyol di Maluku. Jakarta: Komunitas Bambu.

Alwi, Des. 2005. Sejarah Maluku: Bandaneira, Ternate dan Ambon. Jakarta: Penerbit PT. Dian Rakyat.

Cooley. F. 1984. Mimbar dan Takhta. Jakarta: Penerbit SH.

Effendi, Z. 1987. Hukum Adat Ambon - Lease. Jakarta: PT. Pradnya Paramita.

Jansen, H.J. 1977. Indigenous Classification Systems in The Ambonese Moluccas Structural Anthropology in The Nederlands. Edited By Dc Jong P.E. Dc Josselin.

Huliselan, M. 2005. Berdampingan Dalam Perbedaan Konsep Hidup Anak Negeri. dalam Maluku Menyambut Masa Depan. Ambon: Lembaga Kebudayaan Daerah Maluku.

Keuning, .1. 1973. Sejarah Ambon Sampai pada Akhir Abad ke 17. Terjemahan kerja sama antara LIPI dan Koninklijk Instituut voor Tall-Land en Volkenkunde. Penerbit Bhratara Jakarta.

Lapian, A. 2008. Pelayaran dan Perniagaan Nusantara Abad ke 16 dan 17. Jakarta: Komunitas Bambu.
Rumphius. G.E. 2002. de Ambonse Eilanden Onder De VOC. Zoals Opgetekend in Dc Ambonse Landbeschriving. Landelijk Steunpunt Educatie Molukkers. Utrech.

Vickers, A. 2009. Peradaban Pesisir, Menuju Sejarah Budaya Asia Tenggara. Denpasar: Udayana University Press. 